Ethiopian Journal of Environmental Studies \& Management 10(1): 44 - 54, 2017.

ISSN: 1998-0507

doi: http://dx.doi.org/10.4314/ejesm.v10i1.5

Submitted: September 28, 2016

Accepted: January 20, 2017

\title{
RAINFALL CHARACTERISTICS AND OCCURRENCE OF FLOODS IN GOMBE METROPOLIS, NIGERIA
}

\author{
ABASHIYA, M., ${ }^{*}$ ABAJE, I.B., ${ }^{2}$ IGUISI, E.0., 3 BELLO, A.L., ${ }^{3}$ SAWA, B.A., ${ }^{3}$ \\ AMOS, B.B. ${ }^{1}$ AND MUSA, I. ${ }^{1}$ \\ ${ }^{1}$ Department of Geography, Gombe State University, Gombe, Nigeria \\ ${ }^{2}$ Department of Geography and Regional Planning, Federal University, Dutsin-Ma, Nigeria \\ ${ }^{3}$ Department of Geography, Ahmadu Bello University, Zaria, Nigeria
}

\begin{abstract}
Gombe metropolis has been experiencing urban flooding particular in the last two decades. The flood disasters of 2004, 2012 and 2014 in the metropolis were alarming. This paper is aimed at analyzing the rainfall characteristics of Gombe metropolis in order to examine the implications on the occurrence of flooding in the metropolis. Linear trend line equation was used to determine the nature of the rainfall trend. The rainfall series was also sub-divided into 10-year non-overlapping sub-periods in order to identify decadal trends. Rainfall Anomaly Index (RAI) was used to determine years of dryness and wetness. The calculated seasonality index showed that most rain is in July, August and September. The result of the linear trend lines revealed that the increase in the annual rainfall yield is predominantly as a result of an increased in August rainfall. The 5-year running means revealed that rainfall has been increasing from the 2000s to the end of the study period. Findings also showed that the last two sub-periods, 1995-2004 and 2005-2014, depict an increasing rainfall pattern which may be responsible for the floods of $20^{\text {th }}$ August, 2004, 25 th and $30^{\text {th }}$ July, 2012 and $5^{\text {th }}$ September, 2014 that ravaged Gombe metropolis. It is recommended that designing of drainage infrastructures by engineers should take into account the increasing nature of rainfall in the area; government should lay emphasis on policies that steer development away from high risk areas; and there is need to enlighten the general public on the environmental causes of floods.
\end{abstract}

Keywords: Decadal trends, Disaster, Flooding, Linear trends, Metropolis, Wet and dry years

\section{Introduction}

A condition of flood exists when the discharge of a river cannot be accommodated within the margins of its normal channel, thus water spreads over adjoining low-lying grounds on which farmlands or urban structures including residential areas may occupy (Strahler and Strahler, 2003). In recent years, there have been an increased in urban flood disasters that have caused enormous damage in terms of loss of lives and properties. Increase in extreme weather event such as flooding has become an annual recurring

*Corresponding Author: Abaje, I.B.

Email: abajebest@gmail.com 
feature in Nigeria, especially in the northern states (Abaje and Giwa, 2010; Abaje et al., 2015).

The effectiveness and efficiency of urban drainages rely solely on their ability to evacuate excess runoff to prevent flooding. In urban areas where drainages are inadequate or poorly constructed, the resultant effect is frequent flooding (Bello, 1991; Mallo, 1997 and Abashiya, 2006).

The National Emergency Management Agency, NEMA (2013) reported that about 7.7 million people in Nigeria had been affected by flooding between the period July to October, 2012 when 363 were killed and 18,282 injured. The devastating flood event occurred due to heavy downpours in many parts of the country. The flood of August, 2012 along River Niger and Benue that submerged most parts of Lokoja town blocked the major road linking the Northern and Southeastern part of the country. Also the released water from Lagdo Dam in the Cameroun Republic affected parts of Adamawa State in Nigeria.

Studies have shown that northern Nigeria is subject to frequent floods and droughts as a result of its large inter-annual variability of rainfall; and the most devastating impacts of these extreme events especially flood is the washing away of farmlands thereby affecting agricultural production and food security, destruction of houses, increased health risks and the spread of infectious diseases, and changing livelihood systems (Sawa, 2002; Ishaya and Abaje, 2008; Sawa and Adebayo, 2011; Abaje et al, 2014; Abaje et al, 2016). In August, 1988 for example, severe flooding in Kano State resulted in the loss of 146 lives, destruction of 180,000 houses, washing away of 14,000 farms, displacement of 200,000 people, collapsed of the Bagauda Dam and damage to residences and infrastructure worth about 560 million naira (NEST, 1991; Abaje et al., 2014). Similarly, in June 2011, 24 people lost their lives and many others injured, about 100 houses were destroyed, and more than 300 people were displaced after torrential rains flooded the highly populated Fagge area of Kano city (Abaje et al., 2014). Gombe State and particularly its metropolis and environs were not spared. On the $20^{\text {th }}$ of August, 2004, a heavy downpour occurred and generated a flood disaster ever experienced in the last 30 years and killed 35 people, destroyed 1,500 houses, displaced over 30,500 people and damaged property worth over $\$ 2$ million (Ibrahim, 2004).

Flooding in Gombe metropolis has become a yearly phenomenon causing havoc on residents in the metropolis. For instance, on the $25^{\text {th }}$ July 2012, a rainstorm that started at about $2: 30 \mathrm{pm}$ with intermittent breaks and lasted till $8.00 \mathrm{pm}$ left four persons dead, destroyed houses and properties worth over $\$ 11.5$ million. The affected areas in the metropolis were Jeka Dafari, Shamaki, Federal Low-Cost, Bolari, Pantami, Tudun Wada, Barunde and Kumbia-Kumbia (Lawal, 2012). Also, in July 30, 2012, a rainstorm of $59.7 \mathrm{~mm}$ that lasted for about 2 hours caused the collapsed of buildings in Unguwar Madaki, Nassarawa and Pantami areas within the metropolis, three people lost their lives (Anthony, 2012). Similarly, in September 5,2014 , a heavy downpour of $92.5 \mathrm{~mm}$ that lasted for only 48 minutes killed 6 people and damaged properties worth millions of naira in the metropolis. The aim of this paper is to analyze the rainfall characteristics of Gombe metropolis in order to examine the implications on flooding. 
Study Area

Gombe metropolis (Figure 1) is located between latitudes $10^{\circ} 15^{\prime} \mathrm{N}$ and $10^{\circ} 19^{\prime} \mathrm{N}$ and between Longitudes $11^{\circ} 07^{\prime} \mathrm{E}$ and $11^{\circ} 15^{\prime} \mathrm{E}$. It is bounded by Kwami LGA to the North, Akko LGA to the Southwest and YamaltuDeba LGA to the East.

\section{Climate}

Gombe metropolis has a tropical continental type of climate, classified as
Koppen's Aw. It is characterized by strong rainfall seasonality with distinct wet and dry season (Oladipo, 1995). The rainfall is concentrated between the months of May and September with a single maximum in August (Amos, Musa, Abashiya, and Abaje, 2015). The average annual rainfall totals is about 863.2

$\mathrm{mm}$.

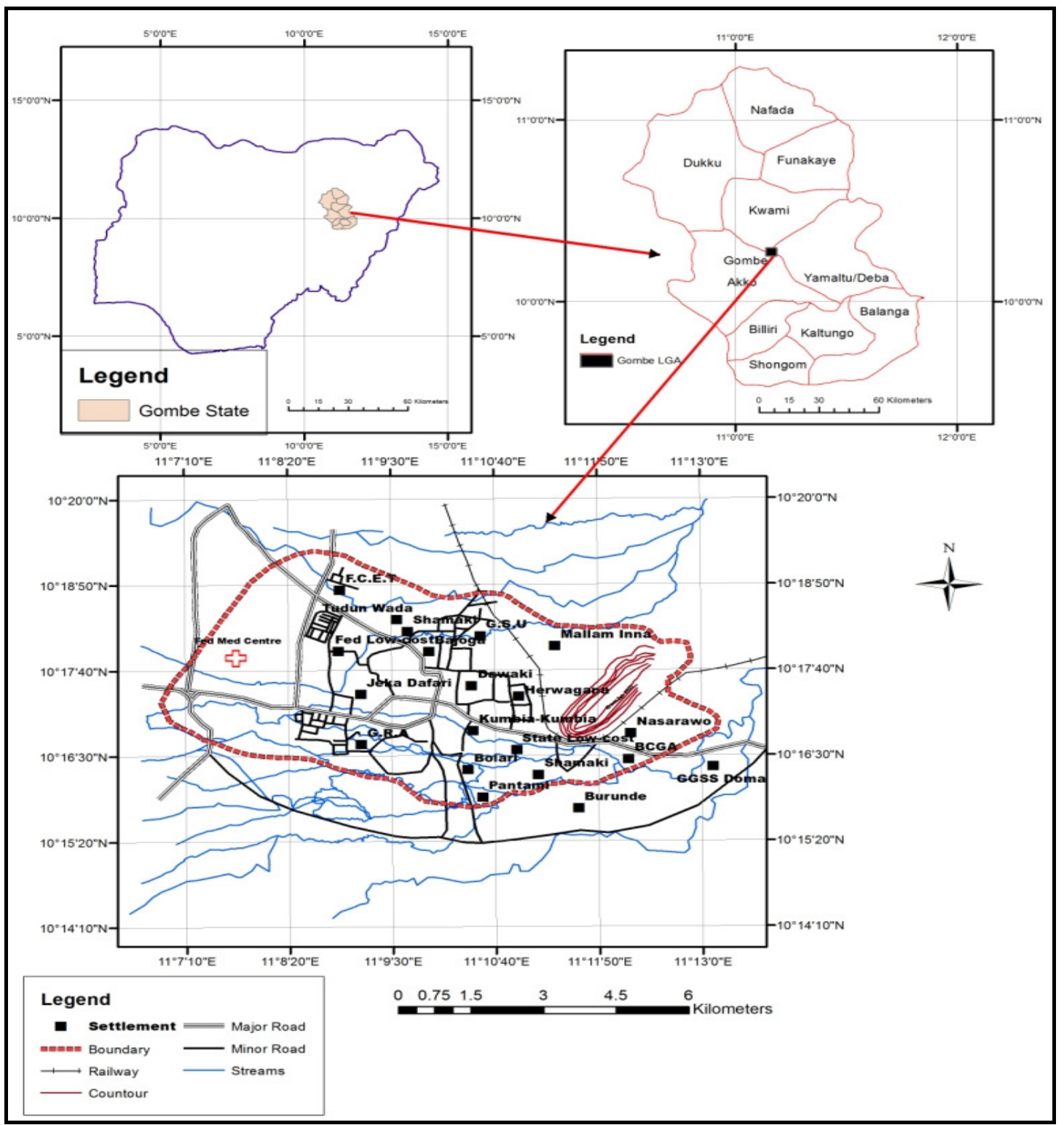

Figure 1: Gombe Metropolis

Source: Adapted from Ministry of Lands and Survey, Gombe State 


\section{Geology and Vegetation}

The bedrock mainly consists of sandstones of cretaceous age, covered by tertiary and quaternary deposits. Gombe metropolis is a low-lying, undulating landscape sloping from Akko escarpment in the west to Liji hill in the east which is the highest point of about $500 \mathrm{~m}$. The metropolis is drained by some ephemeral streams and ravines which take their sources from the Akko escarpment and flow eastwards. The soils are highly ferruginous, formed as a result of intensive weathering of the basement rocks. (Amos et al., 2015). The vegetation is of the Sudan savannah type, characterized by shrubs, scattered trees and grasses (Amos et al, 2015). The predominant tree species include: Parkia (Parkia clappertoniana), Baobab (Adansonia digitata), Tamarind (Tamarindus indica), date palm (Phoenix doctylifera) and Neem (Azadirachta indica) (Abaje, 2007).

\section{Materials and Methods}

Rainfall data of 1975-2014 (40 years) was obtained from the archive of the Nigerian Meteorological Agency (NIMET), Gombe. For this study, only rainfall totals for the rainy months (AprilOctober) and the annual were used. The main reason for using April to October is that $85 \%$ of the total annual rainfall received in the study area is within these months. The normality in the rainfall series was tested using the standardized coefficients of Skewness $\left(Z_{1}\right)$ and Kurtosis $\left(Z_{2}\right)$ statistics as defined by Brazel and Balling (1986). The standardized coefficient of Skewness $\left(\mathrm{Z}_{1}\right)$ was calculated as:

$Z_{1}=\left[\left(\sum_{i=1}^{N}\left(x_{i}-\bar{x}\right)^{3 / N}\right) /\left(\sum_{i=1}^{N}\left(x_{i}-\bar{x}\right)^{2 / N}\right)^{3 / 2}\right] /(6 / N)^{1 / 2}$

and the standardized coefficient of Kurtosis $\left(\mathrm{Z}_{2}\right)$ was determined as:

$Z_{2}=\left[\left(\sum_{i=1}^{N}\left(x_{i}-\bar{x}\right)^{4 / N}\right) /\left(\sum_{i=1}^{N}\left(x_{i}-\bar{x}\right)^{2 / N}\right)^{2}\right]-3 /(24 / N)^{1 / 2}$

Where, $\bar{x}$ is the long term mean of $x_{i}$ values, and $N$ is the number of years in the sample. These statistics were used to test the null hypothesis that the individual temporal samples came from a population with a normal (Gaussian) distribution. If the absolute value of $Z_{1}$ or $Z_{2}$ is greater than 1.96, a significant deviation from the normal curve is indicated at the $95 \%$ confidence level

The Relative Seasonality Index $(S I)$ of the rainfall series was equally calculated using the Walsh and Lawler (1981) statistic. This was done in order to show the class into which the climate of Gombe metropolis can be classified. This index is calculated as:

$S I=\frac{1}{\bar{R}} \sum_{n=1}^{n=12}\left|\bar{x}_{n}-\frac{\bar{R}}{12}\right|$

Where $\bar{x}_{n}$ is the mean rainfall for month $n$ and $\bar{R}$ is the mean annual rainfall. This index can vary from zero (if all the months have equal rainfall) to 1.83 (if all the rainfall occurs in a single month).

Linear trend lines and moving mean were calculated and plotted for both the monthly (April to October) and annual 
rainfall totals $(\mathrm{mm})$ for the station, using Microsoft Excel statistical tool (2013), in order to examine the nature of the trend. In this work, the 5-year moving average was adopted in order to smoothing the time series, thereby reducing the irregular fluctuations and highlighting those that are regular.

The rainfall series was also sub-divided into 10-year non-overlapping sub-periods (1975-1984, 1985-1994 through 20052014. This was done in order to identify decadal trends. The Cramer's test (Lawson et al, 1981) was then used to compare the means of the sub-periods with the mean of the whole record period. The $t$-statistic is computed as:

$$
t_{k}=\left(\frac{n(N-2)}{N-n\left(1+\tau_{k}^{2}\right)}\right)^{1 / 2} \tau_{k}
$$

where $\tau_{k}$ is a standardized measure of the difference between means given as:

$$
\tau_{k}=\frac{\bar{x} k-\bar{x}}{S}
$$

Where $\bar{x} k$ is the mean of the sub-period of n-years, $\bar{x}$ and $S$ are the mean and standard deviation of the entire series respectively and $t_{k}$ is the value of the student $t$ distribution with $N$-2 degrees of freedom. It is then tested against the "students" $t$ distribution table at $95 \%$ confidence level appropriate to a two-tailed form of test, it is accepted that the difference between the overall mean and the mean of certain parts of the record are significant whenever $t_{k}$ is outside the bounds of the two-tailed probability of the Gaussian distribution (equal to 1.96 at $95 \%$ confidence level).

Rainfall Anomaly Index (RAI) is used in depicting periods of dryness and wetness in the area. In this technique, the precipitation values for the period of study were ranked in descending order of magnitude with the highest precipitation being ranked first and the lowest precipitation being ranked last. The average of the ten highest precipitation values as well as that of the ten lowest precipitation values for the period of study was calculated. This technique which was developed by van Rooy (1965) is given by the equation:

$$
\begin{aligned}
R A I= & 3[(p-\bar{p}) /(\bar{m}-\bar{p})] \\
& \text { for positive anomalies and } \\
R A I= & -3[(p-\bar{p}) /(\bar{x}-\bar{p})] \\
& \text { for negative anomalies. }
\end{aligned}
$$

Where, $p$ is the actual rainfall, $\bar{p}$ is the long-term average rainfall, $\bar{m}$ is the mean of the ten highest values of $p$ on record and $\bar{x}$ is the mean of the ten lowest value of $p$ on record. The arbitrary threshold values of +3 and -3 have been assigned to the mean of the ten most extreme positive and negative anomalies respectively. In this study a modified classification of RAI was therefore, adopted. This is because extreme values that is, greater than or equal to 4 and less than or equal to -4 are very infrequent throughout the period of study (1975-2014).

\section{Results and Discussion}

The calculated SI is 1.00 , meaning that most of the rain is in three months or less. The general statistics of the monthly (April-October) and annual rainfall of the study area presented in Table 3 showed that the results of $Z_{1}$ and $Z_{2}$ were accepted as indicative of normality at the $95 \%$ confidence level with the exception of $\mathrm{Z}_{2}$ for the month of August that shows a significant deviation from normal. Therefore, the data was used without any transformation. The table also shows that the peak of the rainy season is in August with a mean rainfall of $232.04 \mathrm{~mm}$ and a standard deviation of 95.40 . 
Table 3: General Statistics of Rainfall (1975-2014) for Gombe Metropolis

\begin{tabular}{lllllllll}
\hline Rainfall $(\mathrm{mm})$ & Apr & May & Jun & Jul & Aug & Sep & Oct & Annual \\
\hline Mean $(\bar{x})$ & 26.36 & 78.05 & 131.03 & 195.12 & 232.04 & 154.21 & 42.06 & 863.2 \\
Standard Deviation $(S D)$ & 25.55 & 43.83 & 46.45 & 65.36 & 95.40 & 63.69 & 26.03 & 173.09 \\
Skewness $\left(Z_{1}\right)$ & 1.12 & 0.82 & 0.45 & 0.37 & 1.52 & 0.88 & -0.03 & -0.20 \\
Kurtosis $\left(Z_{2}\right)$ & 0.61 & 0.34 & 0.58 & -0.52 & $3.61 *$ & 0.18 & -1.13 & -0.85 \\
Trend $(\mathrm{mm} /$ year) & -0.65 & 0.09 & 0.35 & 0.60 & 3.06 & 0.81 & 0.71 & 5.41 \\
Total Change $(\mathrm{mm} / 40$ years) & -2.60 & 3.71 & 13.90 & 24.14 & 122.58 & 32.29 & 28.51 & 216.50 \\
\hline
\end{tabular}

*Significant at $95 \%$ confidence level

Trend analysis of the rainfall data is equally shown in Table 3, while Figure 2a$\mathrm{h}$ shows the graphical presentation of the rainfall trends smoothened out with the 5year running mean. The results of the monthly linear trend lines (Figure 2a-g) for the period of study (1975-2014) clearly showed a general increase in rainfall amount in all the months (even though not significant), with the exception of April that shows a decrease of $2.60 \mathrm{~mm}$ at the rate of $0.65 \mathrm{~mm}$ per year. Estimation of changes of the annual rainfall (Figure 2h) for the period of study indicates an increase of approximately $216.5 \mathrm{~mm}$ at the rate of $5.41 \mathrm{~mm}$ per year. It is therefore, clear from the result of the linear trend lines that the increase in the annual rainfall yield is predominantly as a result of the substantial increased in August rainfall $(122.58 \mathrm{~mm}$ at the rate of $3.06 \mathrm{~mm}$ per year). A general examination of the 5-year running means for all the months (Figure $2 \mathrm{a}-\mathrm{g})$ shows that rainfall has been increasing from the 2000s to the end of the study period. The annual rainfall (Figure 2h) shows that the rainfall was above the long-term mean from 1991 to 1997 and also from 2003 up to the end of the study period (2014). This is a further indication of increasing trends in recent years. The period (1982-1990) in which the 5-year running mean was below the long-term mean coincided with the drought of the 1980 s in the region.

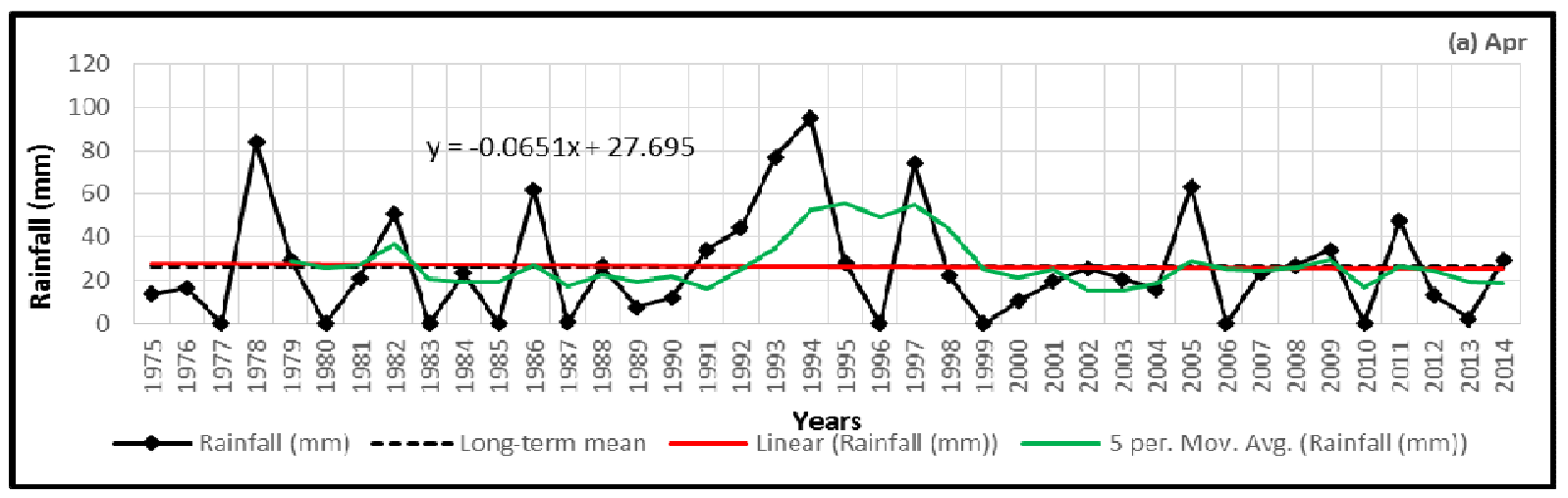




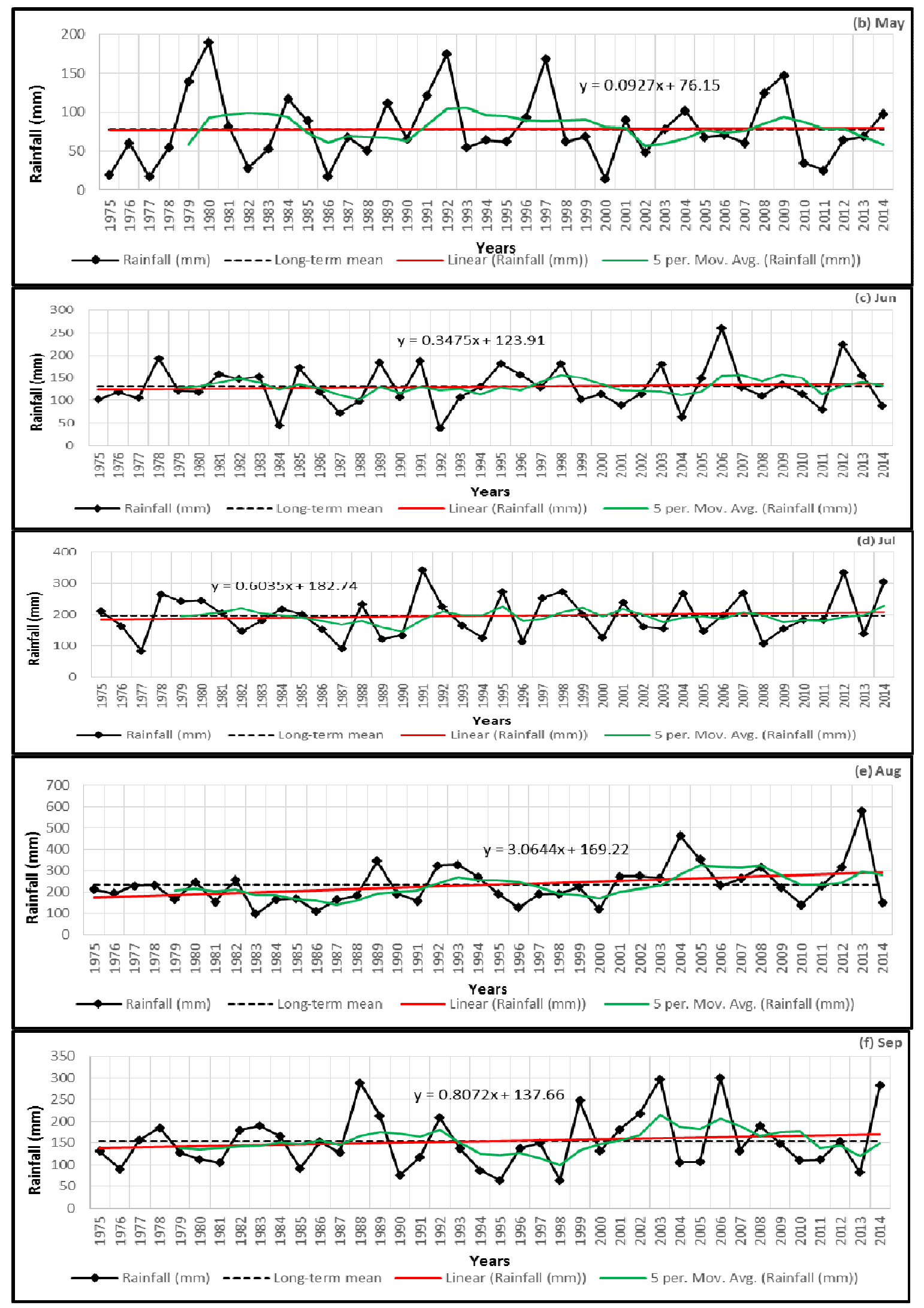




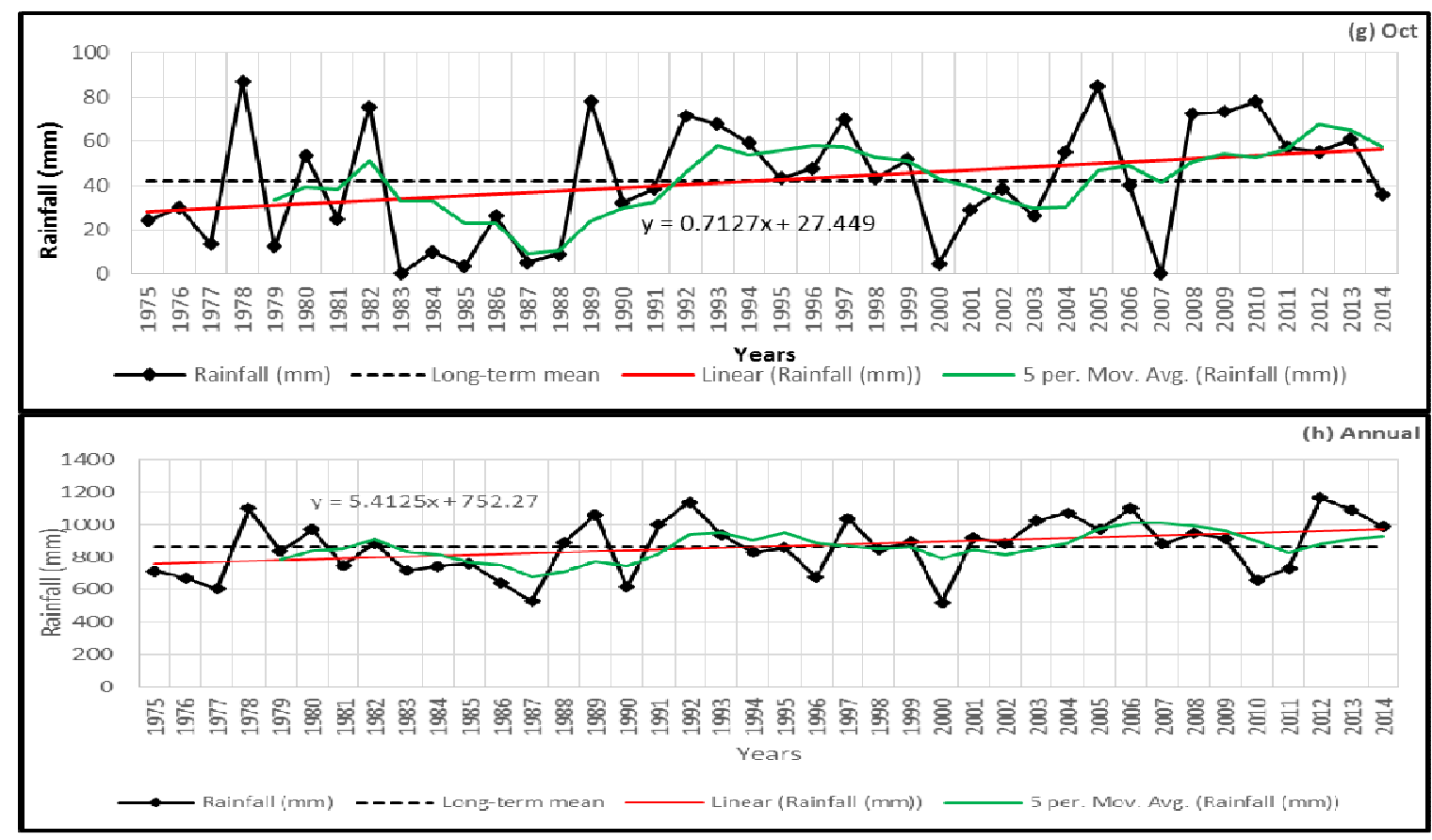

Figure 2: Rainfall Trends for (a) April; (b) May; (c) June; (d) July; (e) August;

(f) September; (g) October; and (h) Annual Totals

The results of the 10-year (decadal) non-overlapping sub-period analysis (Cramer's test) for the monthly and annual rainfall presented in Table 4 showed that the sub-periods 1975-1984 and 1985-1994 were drier than the long-term conditions but not statistically significant at $95 \%$ confidence level. In contrast, the subperiods 1995-2004 and 2005-2014 depicts an increasing rainfall pattern. These subperiods (1995-2004 and 2005-2014) coincided with the recent flood events of 2004, 2012 and 2014 that ravaged the metropolis in which many people lost their lives and properties worth millions of naira were damaged. The increasing rainfall condition in the last two decades correspond with the observations of Odekunle et al. (2008), Abaje et al. (2013), Abaje et al. (2014), and the Nigerian Meteorological Agency, NIMET, (2015) that the sudano-sahelian ecological zone of Nigeria has been experiencing wetness from mid 1990s to recent years. This result is also in agreement with the study of Abaje et al. (2016) in the rural communities of Kaduna State in which the respondents perceived that the occurrence of flood events is increasing in recent years. This scenario has implications on the recent flooding in Gombe metropolis.

Table 4: Results of 10- year non-overlapping sub-period analysis (Cramer's Test)

\begin{tabular}{lllllllll}
\hline Sub-Period & \multicolumn{1}{c}{ Apr } & \multicolumn{1}{c}{ May } & Jun & Jul & Aug & Sep & Oct & Annual \\
\hline $1975-1984$ & -0.35 & -0.14 & -0.35 & 0.01 & -1.32 & -0.53 & -1.18 & -0.11 \\
$1985-1994$ & 1.24 & 0.28 & -0.70 & -0.90 & -0.32 & -0.21 & -0.42 & -0.49 \\
$1995-2004$ & -0.63 & 0.04 & 0.04 & 0.56 & -0.04 & 0.32 & -0.18 & 0.18 \\
$2005-2014$ & -0.32 & -0.18 & 1.02 & 0.35 & 1.57 & 0.42 & 1.64 & 1.49 \\
\hline
\end{tabular}


The occurrence of wet and dry years are presented in Figure 3, while very wet, moderately wet, slightly wet and near normal years are presented in Table 5. An examination of Figure 3 indicates more wet years (23 years) than dry years (17 years) especially during the last two decades. This implies that there is increasing wetness in recent years.

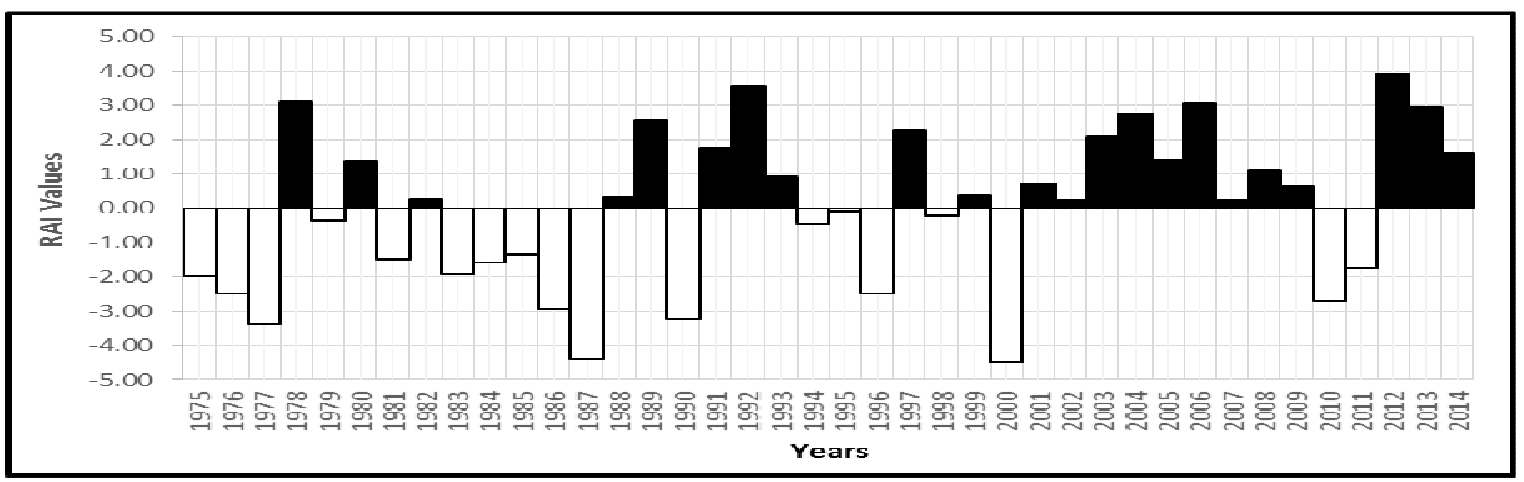

Figure 3: Occurrence of Wet and Dry Years

The occurrence of wet years presented in Table 5 showed that the years 2004, 2012 and 2014 appeared under moderately wet, very wet and slightly wet conditions respectively. This result corresponds with the flood disasters of $20^{\text {th }}$ August, 2004, $25^{\text {th }}$ and $30^{\text {th }}$ July, 2012 and $5^{\text {th }}$ September, 2014 respectively in Gombe metropolis. Field observation in September 5, 2014 also showed inadequate drainages with built-up areas close to the water ways. A close examination of these three categories of wet years (very wet, moderately wet, and slightly wet) showed that nine out of the fourteen years occurred under the last 20 years (1995-2014) which is an indication of increasing rainfall condition.

Table 5: Years of Occurrence of Wet and Normal Conditions in Gombe Metropolis

\begin{tabular}{lll}
\hline Character of Rainfall & Years & Frequency \\
\hline Very wet & $1978,1992,2006$, and 2012 & 4 years \\
Moderately wet & $1989,1997,2003,2004$, and 2013 & 5 years \\
Slightly wet & $1980,1991,2005,2008$, and 2014 & 5 years \\
Near normal & $1979,1982,1988,1993,1994,1995$, & 12 years \\
\hline
\end{tabular}

\section{Conclusion and \\ Policy} Recommendations

The results of the monthly and annual linear trend lines for the period of study (1975-2014) showed a general increase in rainfall amount. The increase in the annual rainfall yield is predominantly as a result of the substantial increased in August rainfall. The 5-year running means shows that rainfall has been increasing from the 2000 s to the end of the study period (2014). The increased in rainfall in recent years, couple with inadequate drainages and residential encroachment to waterways is responsible for the recent flooding events in Gombe metropolis. 
The study recommends that urban planning and designing of drainage infrastructures by engineers should take into account the increasing nature of rainfall in the area. Government should lay emphasis on policies that steer development away from high risk areas. There is need for the people to be enlightened on the environmental causes of floods. This can be done through radio and television programs, issuance of newsletter, booklets, and other media such as mosques (for Muslims) and churches (for Christians). The establishment and improvement of early warning systems by the Nigerian Meteorological Agency to monitor both floods and droughts would help in planning of relief measures that would reduce the loss arising from flooding in the area.

\section{References}

Abaje, I.B. (2007). Introduction to Soils and Vegetation. Kafanchan: Personal Touch Productions.

Abaje, I.B. and Giwa, P.N. (2010). Flood Risk Assessment and Vulnerability in Kafanchan Town, Jema'a Local Government Area of Kaduna State, Nigeria. International Journal of Sustainable Development, 3(1): 94100.

Abaje, I.B., Ati, O.F., Iguisi, E.O. and Jidauna, G.G. (2013). Droughts in the Sudano-Sahelian Ecological Zone of Nigeria: Implications for Agriculture and Water Re-sources Development. Global Journal of Human Social Science (B): Geography, GeoSciences \& Environmental. 13(2): 110.

Abaje, I.B., Ndabula, C. and Garba, A.H. (2014). Is the Changing Rainfall Patterns of Kano State and its
Adverse Impacts an Indication of Climate Change? European Scientific Journal, 10(2): 192-206.

Abaje, I.B., Ogoh, A.O., Amos, B.B. and Abashiya, M. (2015). Climate Change, Flood disaster assessment and Human Security in Katsina State, Nigeria. American Journal of Human Ecology, 4(4): 47-56.

Abaje, I.B., Sawa, B.A., Iguisi, E.O. and Ibrahim, A.A. (2016). Impacts of Climate Change and Adaptation Strategies in Rural Communities of Kaduna State, Nigeria. Ethiopian Journal of Environmental Studies and Management, 9(1): 97 - 108.

Abashiya, M. (2006). Influences of Manmade structures on floods in the Northern parts of Kaduna metropolis, Nigeria. Unpublished M.Sc. Thesis, Department of Geography A.B.U. Zaria.

Amos, B.B., Musa, I., Abashiya, M. and Abaje, I.B. (2015). Impact of Cement Dust Emissions on Soils within 10km Radius in Ashaka area, Gombe State, Nigeria. International Journal of Environment and Pollution, 4(1): 0909-0917.

Anthony, W. (2012). The implications of indiscriminate buildings and incidence of floods. A case study of Arawa Area, Gombe, Gombe State Nigeria. Unpublished B.SC. Project, Department of Geography Gombe State University, Gombe, Nigeria.

Bello, A.L. (1991). Flood hazards potential in Samaru A.B.U. campus, Zaria. Departmental seminar paper No 1 (pp 1 -7). Department of Geography A.B.U. Zaria.

Brazel, S.W. and Balling, R.C. (1986). Temporal analysis of long-term atmospheric moisture levels in 
Phoenix, Arizona. Journal of Climate Change and Applied Meteorology, 25: 112-117.

Ibrahim, S. (2004). Gombe flood kills 35 people, destroyed 1,500 houses. This Day, August 25, 2004, p 5.

Ishaya, S. and Abaje, I.B. (2008). Indigenous People's Perception on Climate Change and Adaptation Strategies in Jema'a Local Government Area of Kaduna State, Nigeria. Journal of Geography and Regional Planning, 1(8): 138-143.

Lawal, I. (2012). Rainstorm kills four, destroyed houses in Gombe. Daily Trust, $\mathrm{p} 6$.

Lawson, M.P. Balling, R.C. Peters, A.J. and Rundquist, D.C. (1981) Spatial analysis of secular temperature fluctuations. Journal of Climatology, 1: 325-332.

Mallo, I.I.Y. (1997). Some response of geomorphic processes to urbanization in Barnawa River catchment, Kaduna metropolis, Northern Nigeria. Unpublished Ph.D. Thesis. Department of Geography ABU Zaria.

National Emergency Management Agency. (2013). Flood Disaster Report 2012. Daily Trust Newspaper.

Nigerian Environmental Study/Action Team, NEST. (1991). Nigeria's Threatened Environment: A National Profile. A NEST Publication, Ibadan.

Nigerian Meteorological Agency, NIMET. (2015). 2015 Nigeria Climate Review
Bulletin (63 pp). Nigerian Meteorological Agency (NIMET), Abuja.

Odekunle, T.O., Andrew, O. and Aremu, S.O. (2008). Towards a wetter sudano-sahelian ecological zone in twenty first century Nigeria. Weather, 63(3): 66-70.

Oladipo, E.O. (1995). Some statistical characteristics of drought area variations in the savannah region of Nigeria. Theoretical and Applied climatology, 50: 147-155.

Sawa, B.A. (2002). Trend in temporal variability of occurrence of wet and dry spells north of latitude $10^{\circ} \mathrm{N}$ in Nigeria. In Iguisi, E. O. (Ed). The Zaria Geographer 15(1): 34-41.

Sawa, B.A. and Adebayo, A.A. (2011). The impact of climate change on precipitation effectiveness indices in Northern Nigeria. Research Journal of Environmental and Earth Sciences, 3(5): 481-486.

Strahler, A.N. and Strahler, A.H. (2003). Introducing Physical Geography ( ${ }^{\text {rd }}$ ed) John Wiley and Sons Inc Cambridge. M. A. (pp 499-502).

VanRooy, M.P. (1965). A rainfall anomaly index independent of time and space. Notos, 14: 43-48.

Walsh, R.P.D. and Lawler, D.M. (1981). Rainfall seasonality: description, spatial patterns and change through time. Weather, 36: 201-208. 